\title{
Distribution of zooplankton community in Toli shad (Tenualosa toli) habitats, Sarawak, Malaysia
}

\author{
WAN MOHAMAD AIMAN ${ }^{1}$, FATIMAH MD YUSOFF ${ }^{3}$, AZIZ ARSHAD ${ }^{3}$, ABU HENA MUSTAFA KAMAL ${ }^{2, \vartheta}$, \\ JOHAN ISMAIL ${ }^{1}$, MOHD HANAFI IDRIS ${ }^{2}$, NURUL ULFAH KARIM ${ }^{2}$, ABDULLA AL ASIF ${ }^{1}$ \\ ${ }^{1}$ Department of Animal Science and Fishery, Faculty of Agriculture and Food Sciences, Universiti Putra Malaysia Campus Bintulu. Nyabau Rd, 97008 \\ Bintulu, Sarawak, Malaysia \\ ${ }^{2}$ Faculty of Fisheries and Food Science, Universiti Malaysia Terengganu. 21030 Kuala Nerus, Terengganu, Malaysia. \\ Tel./fax.: +60-9-6685001, `email: a.hena@umt.edu.my \\ ${ }^{3}$ Department of Aquaculture, Faculty of Agriculture, Universiti Putra Malaysia. Serdang 43400, Selangor Darul Ehsan, Malaysia
}

Manuscript received: 25 April 2020. Revision accepted: 10 August 2020.

\begin{abstract}
Aiman WM, Yusoff FM, Arshad A, Kamal AHM, Ismail J, Idris MH, Karim NU, Asif AA. 2020. Distribution of zooplankton community in Toli shad (Tenualosa toli) habitats, Sarawak, Malaysia. Biodiversitas 21: 4022-4033. The river ecosystems of Sarawak has been identified as important-spawning ground for economically important Toli shad (Tenualosa toli) fisheries. In these river ecosystems, zooplankton serves as a secondary producer to the different types of fish larvae including Toli shad. The productivity and biomass of zooplankton are important factors to control the production of higher trophic level organisms like fish larvae and fishes in different stages including T. toli larvae. In this viewpoint, the composition and abundance of zooplankton were investigated at 5 (five) sampling stations (considered to be spawning and nursing areas of Toli shad) at Batang Lupar and Batang Sadong estuaries from July 2016 to June 2017 . A total of 29 zooplankton taxa were recorded that belong to 14 major groups comprised of Copepoda (Arthropoda), Crustacean nauplii (Arthropoda), Fish larvae (Chordata), Mollusca (Mollusca), Luciferidae (Arthropoda), Cnidaria (Cnidaria), Ostracoda (Arthropoda), Cirripedia (Arthropoda), Polychaete larvae (Annelida), Chaetognatha (Chaetognatha), Appendicularia (Chordata), Amphipoda (Arthropoda), Echinodermata larvae (Echinodermata) and Cladoceran (Arthropoda). Copepod was dominant group of zooplankton (82.40$94.41 \%$ ) at all stations, contributing $477.37-25921.89 \mathrm{ind} / \mathrm{m}^{3}$ and $88.38 \%$ of total abundance. The second highest was crustacean larvae $(2.45-9.38 \%)$ in all stations, contributing $0-2391.7 \mathrm{ind} / \mathrm{m}^{3}$ and $5.88 \%$ of total abundance. Zooplankton abundance was higher at downstream station $1\left(8460.72 \mathrm{ind} / \mathrm{m}^{3}\right)$ followed by station $2\left(5479.80 \mathrm{indi} / \mathrm{m}^{3}\right)$, station $3\left(4571.95 \mathrm{ind} / \mathrm{m}^{3}\right)$, station $4\left(4394.20 \mathrm{ind} / \mathrm{m}^{3}\right)$ and upstream station $5\left(4156.73 \mathrm{ind} / \mathrm{m}^{3}\right)$. Canonical Correspondence Analysis showed that the abundance of copepods was highly influenced by total turbidity and nitrate in the riverine and estuarine ecosystems. Abundance of zooplankton was relatively higher $\left(9549.31 \mathrm{ind} / \mathrm{m}^{3}\right) \mathrm{during}$ the post-monsoon and lower $\left(3534.56 \mathrm{ind} / \mathrm{m}^{3}\right)$ during the southwest monsoon.
\end{abstract}

Keywords: Malaysia, Sarawak, Toli shad, Tropical Borneo, zooplankton

\section{INTRODUCTION}

The presence of zooplankton is the key indicator of the healthiness of a water body (Ismail and Adnan 2016). It also plays a significant ecological role in the food web in any aquatic ecosystem (Cook et al. 2007). It recycles micro-macro nutrients including organic matter transformation (Edwards, 2001) from primary producers to secondary consumers like fishes (Thirunavukkarasu et al. 2013). High-value commercial fishes mainly Toli shad (Tenualosa toli) used to migrate turbid and brackish estuary (Mohsin and Ambak 1996) for spawning and nursing in Sarawak waters, Malaysia, where zooplankton community plays a vibrant role for nourishment to different commercial species up to juvenile from larvae including Toli shad (Tumiran et al. 2011; Rahim et al. 2014). Studies showed that the seasonal distribution and abundance of zooplankton represented in dissimilar patterns throughout the season in a year elsewhere (Srichandan et al. 2013; Buttay et al. 2015; Marcolin et al. 2015; Abu Hena et al. 2016; Abdullah et al. 2018).
Estuaries are usually non-isolated and highly tidal region with the change of all physicochemical parameters that influence the planktonic food sources for fishes found in tropical estuarine ecosystems (Harrison 2004; Hossain et al. 2012; Saifullah et al. 2014; Paturej et al. 2017). Previously, Chew and Chong (2010); Rezai et al. (2011); Lee (2012); Zaleha et al. (2013); Zulikha et al. (201)3; Kassim et al. ( 2015); Matias-Peralta and Yusoff (2015); Musa and Singh (2015); Azmi et al. (2016); Fatema and Omar (2016); Saidin (2016); Yong et al. (2016); Kamaruzaman et al. (2018) had documented the seasonal distribution of zooplankton from both the riverine and estuarine water of Malaysia. Although several studies have been undertaken in Peninsular Malaysia, a few zooplankton studies dealt in the estuarine and riverine habitats in east Malaysia (Jivaluk 1999; Johan et al. 2013; Sinev and Yusoff 2015; Sinev and Yusoff 2018). Furthermore, there are no previous studies revealed on the temporal population structure of zooplankton in Sarawak riverine and estuarine waters, which is very well known for the historical $T$. toli shad spawning (Rahim et al. 2014) and nursery ground. Considering an important breeding area of a high valued 
commercial species, this study was undertaken to assess the zooplankton availability, abundance and ecological interactions in one of the Toli shad habitats, namely Batang Lupar and Batang Sadong estuaries, Sarawak. The findings of this study help to know the zooplankton community and distribution in these estuarine ecosystems which would help to understand the spatial and temporal distribution of zooplankton of Toli shad breeding ground along with their ecosystem functions. The findings of this study eventually are usual for habitat conservation and sustainable management of this important fishery resources in Sarawak waters, Malaysia.

\section{MATERIALS AND METHODS}

The study was conducted in the south-western part of Sarawak, the Batang Lupar and Batang Sadong estuarine complex. Five (5) sampling stations (Figure 1) were selected along the Batang Lupar and Batang Sadong estuaries encompassing the importance for the spawning ground of Tenualosa toli and all sampling locations relocated with a differentially corrected Global Positioning System (GPS) receiver (Model Garmin, GPS 76, SN 80308437, Olathe USA). The field samples collected from surface water from the selected stations monthly from July 2016 to June 2017.

\section{Collection and identification of zooplankton}

Zooplankton was collected monthly for 12 consecutive months (a year) from surface waters ( $<1 \mathrm{~m}$ depth) of the selected area using a zooplankton net of $150 \mu \mathrm{m}$ mesh size with $0.35 \mathrm{~m}$ mouth diameter (Sameoto et al. 2000). All samples were done at three replication. The flow meter was mounted at the center of the mouth of net to measure the rate or quantity of water passed into the net (Smith et al. 1968) and the net was towed horizontally at the surface for 5 minutes following Wiebe et al. (2014). Collected samples were put into a $250 \mathrm{ml}$ plastic bottle and preserved by neutralized 5\% formalin. All samples were brought to the Aquatic Laboratory of Universiti Putra Malaysia Bintulu Sarawak Campus for further analysis and identified following Chihara and Murano (1997).

The major taxonomic groups of zooplankton were determined under the microscope (Leica, Model: Z45V) using a counting chamber. Samples were analyzed for the determination of zooplankton diversity and abundance using standard works of Kasthuriranagn (1963). Zooplankton samples were fractioned before analysis using Motodo Plankton Splitter. Zooplankton abundance was calculated based on total area hauled by the plankton net and volume of water filtered was measured by the following equations:

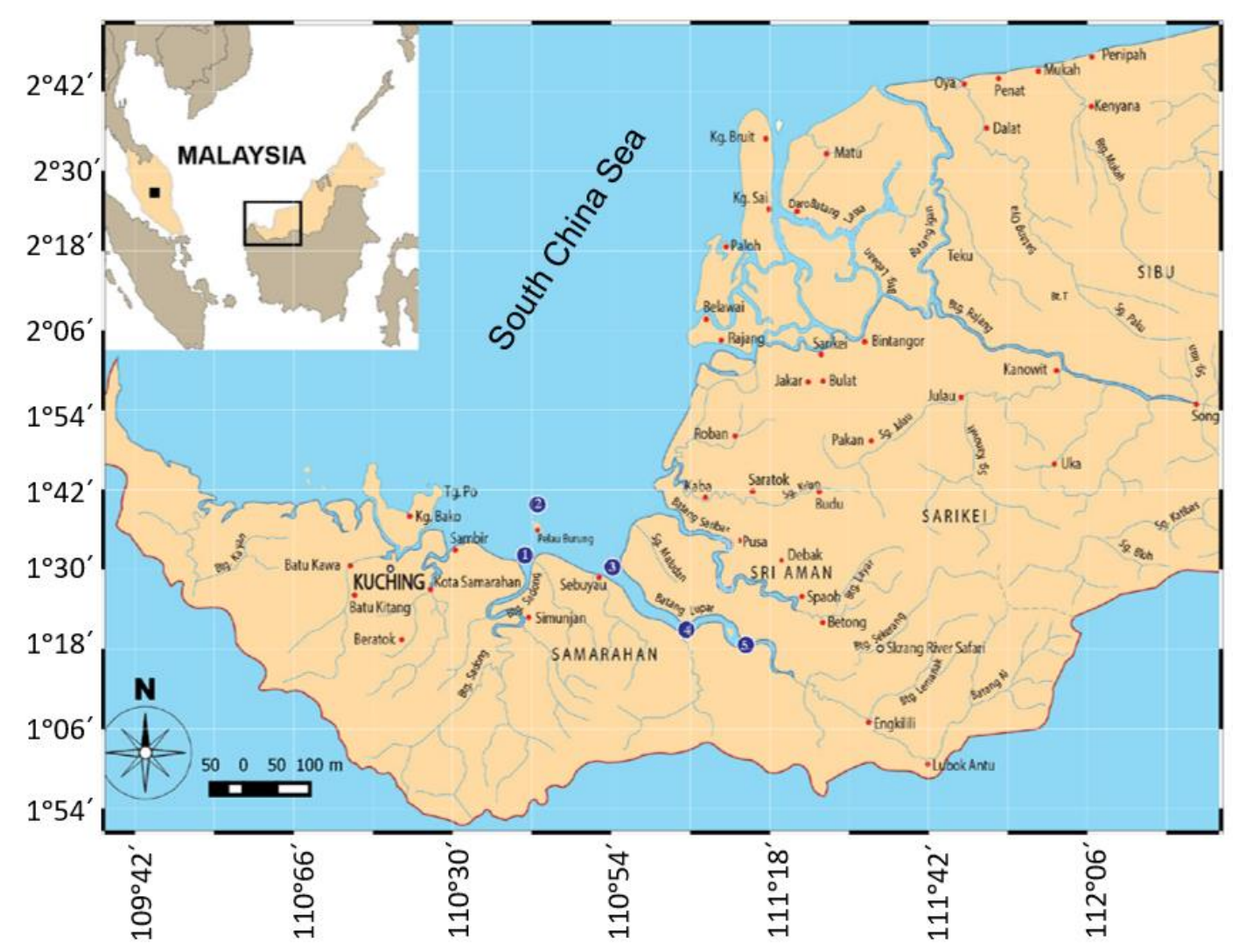

Figure 1. Map of the study area showing sampling location (Stations 1 to 5) in Batang Lupar and Batang Sadong estuaries, Sarawak, Malaysia 
The volume of water filtered through the zooplankton net was calculated by the equation of,

The volume of filtered water $=\pi r^{2} d\left(\mathrm{~m}^{3}\right)$

Where, $r$ : radius of the mouth of the plankton net $(\mathrm{m})$, and pie: $3.142, d$ : Length of the water column traversed by the net. Total hauling area $(\mathrm{d}): 1$ meter $*$ flow meter reading ( 5 rotor count is equal to $1 \mathrm{~m}$ )/flow meter standard.

Then the abundance of zooplankton was calculated by the following equation:

The abundance of zooplankton (individual $/ \mathrm{m}^{3}$ ) = Number of counted specimen

wolume of water filtered

\section{Collection of ecological samples and analysis of ecological parameters}

In-situ parameters of surface water were measured in all stations, including temperature, salinity, $\mathrm{pH}$, dissolved oxygen, conductivity, and turbidity by using multiparameter (Model Hydro-lab, WQC-24). Water samples were collected randomly from the water surface of river estuary from three sampling areas (replications) of a station by following Environmental Protection Agency guidelines, EPA (2008). In the laboratory, water nutrients including total suspended solids (TSS), chlorophyll $a$, ammonia $\left(\mathrm{NH}_{3}\right)$, nitrate $\left(\mathrm{NO}_{3}\right)$, phosphate $\left(\mathrm{PO}_{4}\right)$ and Silica $\left(\mathrm{SiO}_{2}\right)$ analyzed. Water nutrients were analyzed by APHA standard methods (2005) in the laboratory. The data of zooplankton diversity and other ecological factors were transformed and performed the normality test. normality Then a two-way ANOVA was performed on various abiotic factors and zooplankton groups to find out the variations in physicochemical parameters, population density, species diversity, and diversity index. The Shannon-Wiener index $\left(H^{\prime}\right)$ was used to summarize the information on the relative abundance of zooplankton found within the study area. The relationship between physicochemical parameters and population abundance of zooplankton was analyzed using the Canonical Correspondence Analysis (CCA). Zooplankton abundance according to stations were classified using cluster analysis, and similarity (ANOSIM) by using MVPS 3.1 and PAST (3.0) version software.

\section{RESULTS AND DISCUSSION}

\section{Zooplankton diversity}

A total of 29 zooplankton species was recorded in the present study which belongs to 14 major groups of zooplankton (Table 1) represented by Copepoda, Crustacean nauplii, Fish larvae, Mollusca, Luciferidae, Cnidaria, Ostracoda, Cirripedia, Polychaete larvae, Chaetognatha, Appendicularia, Amphipoda, Echinodermata larvae and Cladocera.

Table 1. Major groups of zooplankton at toli shad breeding ground area, in Sarawak, Malaysia

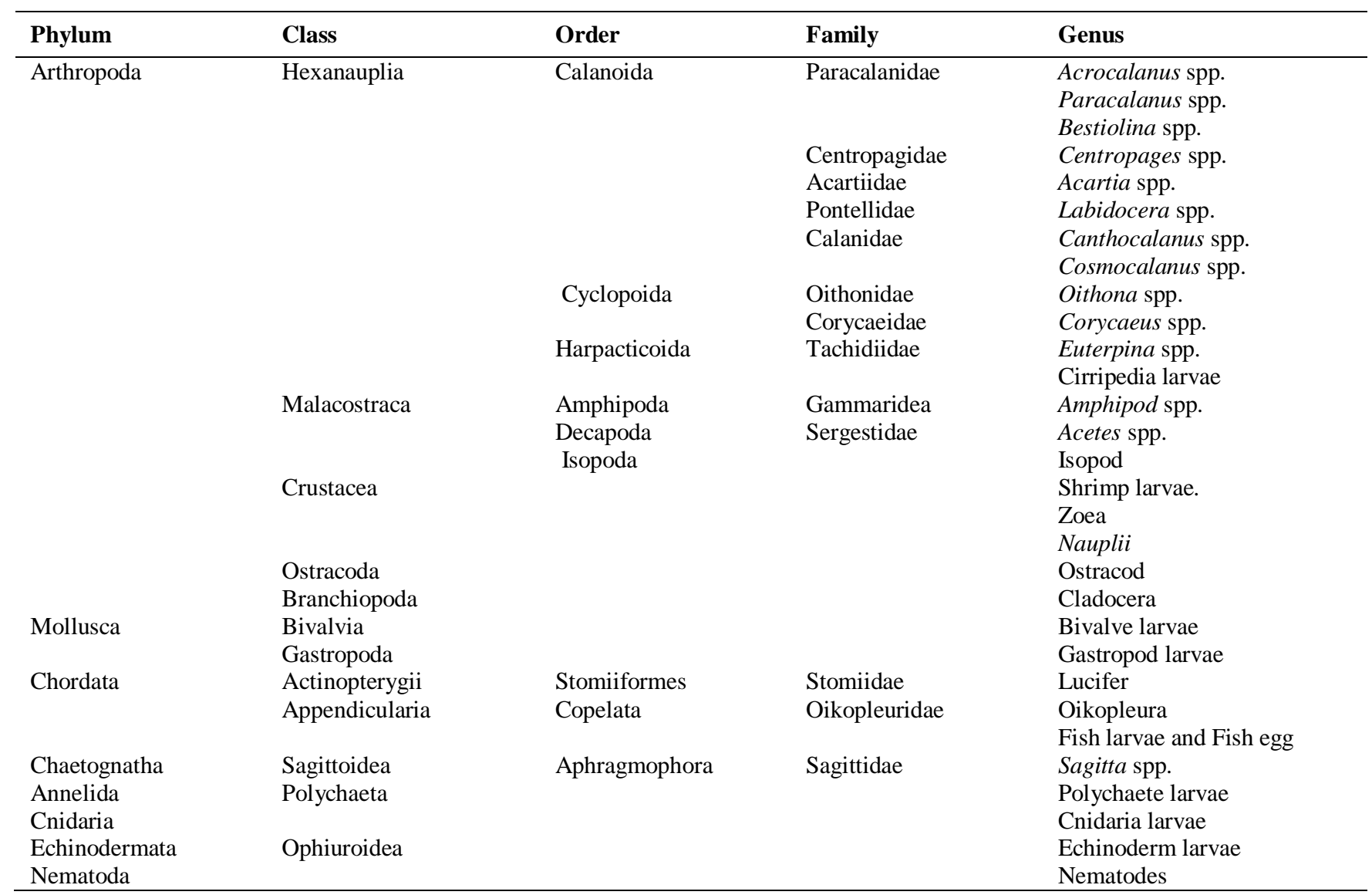


Percentage of zooplankton group from Tenualosa toli breeding area

The present study reported that copepods were the major group $(88.38 \%)$ of species during the whole study period, and non-copepods comprised $11.62 \%$ in the total species counted. Non-copepod comprised with Crustaceans larvae $(5.88 \%)$, Chaetognatha $(2.32 \%)$, Mollusca (1.95\%), Polychaeta $(0.88 \%)$, Cnidaria $(0.19 \%)$, Fish larvae $(0.13 \%)$ and others $(0.27 \%)$ groups from this Batang Lupar river estuary (Figure 2).

\section{Zooplankton abundance}

The total population densities of zooplankton ranged from 447.5 to $27812.9 \mathrm{ind} / \mathrm{m}^{3}$ representing from five stations (Figure 3), and the dominant group, copepod contributed about $477.37-25921.89 \mathrm{ind} / \mathrm{m}^{3}$. Zooplankton abundance in station 1 was higher $\left(8460.72 \mathrm{ind} / \mathrm{m}^{3}\right)$ followed by station $2\left(5479.80 \mathrm{ind} / \mathrm{m}^{3}\right)$, station $3(4571.95$ ind $\left./ \mathrm{m}^{3}\right)$, station $4\left(4394.2 \mathrm{ind} / \mathrm{m}^{3}\right)$ and station $5(4156.73$ ind $/ \mathrm{m}^{3}$ ) (Figure 4). The highest total means zooplankton abundance $\left(10070.39 \mathrm{ind} / \mathrm{m}^{3}\right)$ was recorded in December 2016 while the lowest abundance $\left(1461.47 \mathrm{ind} / \mathrm{m}^{3}\right)$ was observed in July 2016 (Table 2).

The abundance and distribution of zooplankton at all stations showed that copepod was the dominant group in terms of composition (Figure 5). Copepod showed $86.05 \%$, $90.57 \%, 82.40 \%, 90.82 \%$ and $94.41 \%$ in total zooplankton population in stations 1, 2, 3, 4 and 5, respectively. Second important group was Crustacean nauplii $(2.45 \%$ to $9.38 \%)$ followed by Chaetognatha $(0.30 \%$ to $6.64 \%)$ and Mollusca $(0.12 \%$ to $3.87 \%)$.

\section{Ecological parameter}

Water salinity and conductivity were significantly different $(p<0.05)$ in all stations; while, these values were found higher at stations 1,2 , and 3 but lower at stations 4 and 5 (Table 3). Salinity (16.48 to 46.97 PSU) and conductivity (24.66 to $57.52 \mathrm{~S} / \mathrm{m})$ were the higher at stations 1, 2, and 3 in July, August, September, April, May, and June. Turbidity and total suspended solids showed almost similar trends but, not significantly $(p \geq 0.05)$ different. The surface water temperature at all stations was at the range of $26.0^{\circ} \mathrm{C}$ to $26.48^{\circ} \mathrm{C}$ (north-west monsoon) from January to April, while in July to December recorded in higher trend from $28^{\circ} \mathrm{C}$ to $31.39^{\circ} \mathrm{C}$ (Figure 6). The temperature was not significantly different $p \geqq 0.05$ among the station studied (Table 3). The highest water temperature was recorded $\left(31.39^{\circ} \mathrm{C}\right)$ in August at station 3 and the lowest $\left(21.95^{\circ} \mathrm{C}\right)$ in June at station 5 .

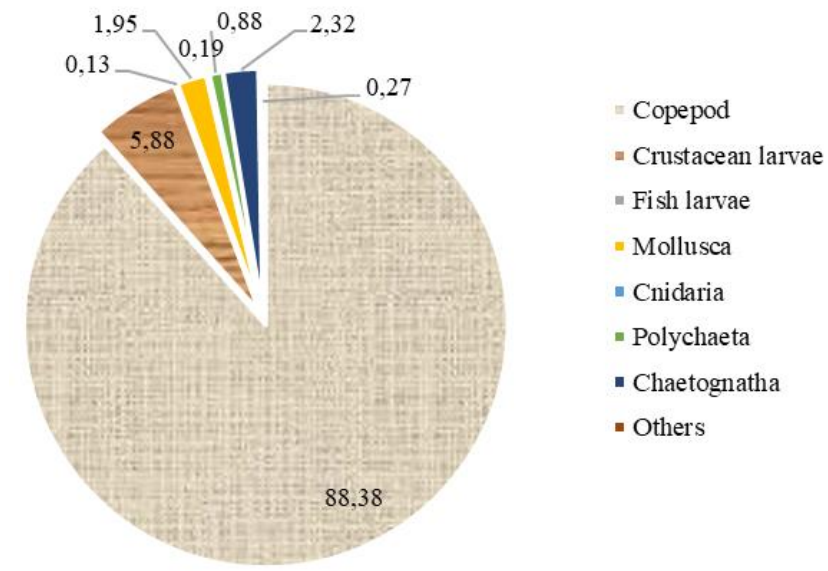

Figure 2. Percentage of zooplankton group from toli shad (Tenualosa toli) breeding ground area during the study period in Sarawak, Malaysia

Table 2. Summary result of two-way ANOVA and Tukey HSD tests on various zooplankton groups (mean (ind $\left./ \mathrm{m}^{3}\right) \pm \mathrm{SE}$ )

\begin{tabular}{|c|c|c|c|c|c|c|}
\hline Zooplankton & Station 1 & Station 2 & Station 3 & Station 4 & Station 5 & \\
\hline Copepoda & $7301.84 \pm 2075.13^{a}$ & $4277.8 \pm 1265.4^{\mathrm{a}}$ & $3854.4 \pm 605.9^{\mathrm{a}}$ & $3955.6 \pm 908.6^{\mathrm{a}}$ & $4197.8 \pm 1152.7^{\mathrm{a}}$ & $\mathrm{ns}$ \\
\hline Crustacean nauplii & $618.15 \pm 228.22^{\mathrm{a}}$ & $230.93 \pm 81.2^{\mathrm{a}}$ & $438.95 \pm 185.7^{\mathrm{a}}$ & $171.83 \pm 107.4^{\mathrm{a}}$ & $108.95 \pm 41.5^{\mathrm{a}}$ & ns \\
\hline Fish larvae & $6.47 \pm 2.92^{\mathrm{a}}$ & $13.53 \pm 5.27^{\mathrm{a}}$ & $3.85 \pm 1.25^{\mathrm{a}}$ & $6.32 \pm 2.08^{\mathrm{a}}$ & $4.59 \pm 2.36^{\mathrm{a}}$ & ns \\
\hline Mollusca & $328.89 \pm 259.83^{\mathrm{a}}$ & $33.76 \pm 11.23^{\mathrm{a}}$ & $5.43 \pm 2.19^{\mathrm{a}}$ & $41.26 \pm 15.07^{\mathrm{a}}$ & $111.13 \pm 83.2^{\mathrm{a}}$ & ns \\
\hline Luciferidea & $1.00 \pm 0.66^{\mathrm{a}}$ & $1.60 \pm 1.25^{\mathrm{a}}$ & $2.31 \pm 1.79^{\mathrm{a}}$ & $0.00^{\mathrm{a}}$ & $0.00^{\mathrm{a}}$ & ns \\
\hline Cnidaria & $8.36 \pm 8.05^{\mathrm{a}}$ & $25.65 \pm 18.31^{\mathrm{a}}$ & $2.67 \pm 1.55^{\mathrm{a}}$ & $12.34 \pm 6.75^{\mathrm{a}}$ & $1.18 \pm 0.69^{\mathrm{a}}$ & ns \\
\hline Ostracoda & $11.12 \pm 10.89^{\mathrm{a}}$ & $2.32 \pm 1.57^{\mathrm{a}}$ & $2.80 \pm 2.58^{\mathrm{a}}$ & $1.60 \pm 1.6^{\mathrm{a}}$ & $0.00^{\mathrm{a}}$ & ns \\
\hline Cirripedea & $10.59 \pm 9.13^{\mathrm{a}}$ & $0.18 \pm 0.18^{\mathrm{a}}$ & $0.46 \pm 0.46^{\mathrm{a}}$ & $1.57 \pm 1.34^{\mathrm{a}}$ & $2.14 \pm 1.21^{\mathrm{a}}$ & ns \\
\hline Polychaeta & $79.66 \pm 69.64^{\mathrm{a}}$ & $47.90 \pm 43.94^{\mathrm{a}}$ & $53.62 \pm 50.58^{\mathrm{a}}$ & $46.82 \pm 33.14^{\mathrm{a}}$ & $5.80 \pm 3.81^{\mathrm{a}}$ & ns \\
\hline Chaetognatha & $101.31 \pm 35.61^{\mathrm{ab}}$ & $81.32 \pm 34.91^{\mathrm{ab}}$ & $310.51 \pm 102.3^{\mathrm{a}}$ & $113.60 \pm 71.46^{\mathrm{ab}}$ & $13.28 \pm 5.66^{\mathrm{b}}$ & $* *$ \\
\hline Appendicularidae & $16.98 \pm 10.95^{\mathrm{a}}$ & $5.66 \pm 2.57^{\mathrm{a}}$ & $2.53 \pm 0.98^{\mathrm{a}}$ & $2.04 \pm 1.64^{\mathrm{a}}$ & $0.19 \pm 0.19^{\mathrm{a}}$ & ns \\
\hline Amphipoda & $1.35 \pm 0.63^{\mathrm{a}}$ & $1.10 \pm 1.1^{\mathrm{a}}$ & $0.16 \pm 0.16^{\mathrm{a}}$ & $2.57 \pm 2.41^{\mathrm{a}}$ & $1.23 \pm 0.66^{\mathrm{a}}$ & ns \\
\hline Echinodermata & $0.40 \pm 0.0^{0 \mathrm{a}}$ & $1.28 \pm 1.28^{\mathrm{a}}$ & $0.00^{\mathrm{a}}$ & $0.00^{\mathrm{a}}$ & $0.00^{\mathrm{a}}$ & ns \\
\hline Cladocerans & $0.00^{\mathrm{a}}$ & $0.12 \pm 0.12^{\mathrm{a}}$ & $0.00^{\mathrm{a}}$ & $0.00^{\mathrm{a}}$ & $0.00^{\mathrm{a}}$ & ns \\
\hline
\end{tabular}

Note: *Correlation is significant at 0.05 level (2-tailed). $* *$ Correlation is significant at 0.01 level (2-tailed) 
Water $\mathrm{pH}$ was significantly different $p \leq 0.01$ in all stations. Riverine and estuarine water were alkaline (7.0 to 8.25) at all stations in July, August and September, while from October to June it was slightly acidic (stations 1 to 3 ) to alkaline (stations 4 and 5), and ranged from 6.75 to 7.5. Dissolved oxygen (DO) was significantly different $(p \leq 0.05)$, and found higher in May and June at stations 1 to $3(5.27$ to $10.6 \mathrm{mg} / \mathrm{l})$ and lower in other months in other stations with the range of 3.0 to $6.25 \mathrm{mg} / \mathrm{l}$. The maximum mean value of total suspended solids was found at station 1 in July $(0.83 \mathrm{mg} / \mathrm{l})$, while the lowest value at station 2 in November $(0.06 \mathrm{mg} / \mathrm{l})$, but not significantly different at all stations. Chlorophyll $a$ ranged from 0.001 to $0.07 \mathrm{mg} / \mathrm{l}$ ) during the study period. Water nutrients (ammonium, nitrate, phosphate), total suspended solids, chlorophyll $a$, and silica showed a non-significant trend $(p \geqq 0.05)$ (Table 3) in all stations (Figure 7).

\section{Ecological indices}

The richness index (1.07 to 1.54$)$ was higher at station 2 where 13 zooplankton groups and lowers at station 5 which comprised nine zooplankton groups. Both the Shannon and evenness indices were the highest at station 3 and the lowest at station 5 which Shannon indices were within the range of 0.28 to 0.64 and evenness indices were within 0.12 to 0.26 (Figure 8 ).

\section{ANOSIM analysis of zooplankton population abundance}

The similarity of zooplankton abundance among all stations based on the number of zooplankton found per $\mathrm{m}^{3}$ data (permutation: 9999) revealed that there were no significant differences $(\mathrm{p}<0.30)$ among stations. The study also revealed that some stations that were located in a similar habitat shared high similarity in abundance among the stations. The study revealed, station 1 was very similar with station 2 (similarity index: 0.18 ), and very dissimilar with station 3 (similarity index: 0.32); station 2 was very similar with station 3 (similarity index: 0.11 ), and very dissimilar with station 4 (similarity index: 0.43 ); station 3 was very similar with station 2 (similarity index: 0.11 ), and very dissimilar with station 5 (similarity index: 0.61); station 4 was very similar with station 1 (similarity index: 0.25 ), and very dissimilar with station 3 (similarity index: 0.62 ); station 5 was very similar with station 2 (similarity index: 0.29), and very dissimilar with station 3 (similarity index: 0.67) (Table 4).

Table 3. Summary results of two-way ANOVA and Tukey HSD tests on various abiotic factors (mean \pm SE)

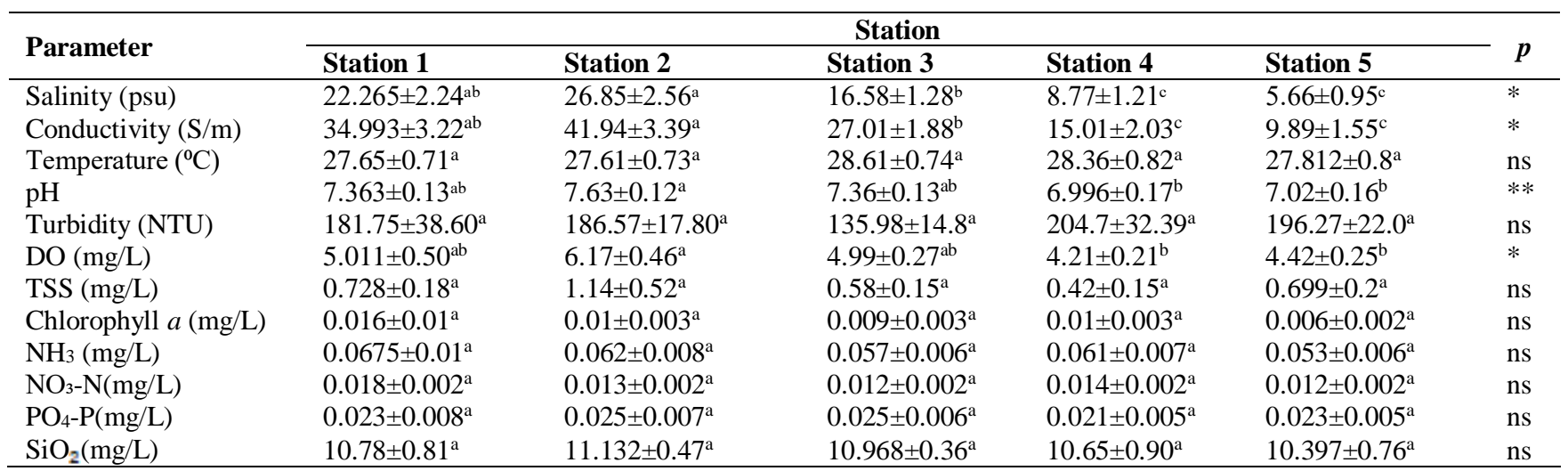

Note: *Correlation is significant at 0.05 level (2-tailed). **Correlation is significant at 0.01 level (2-tailed).

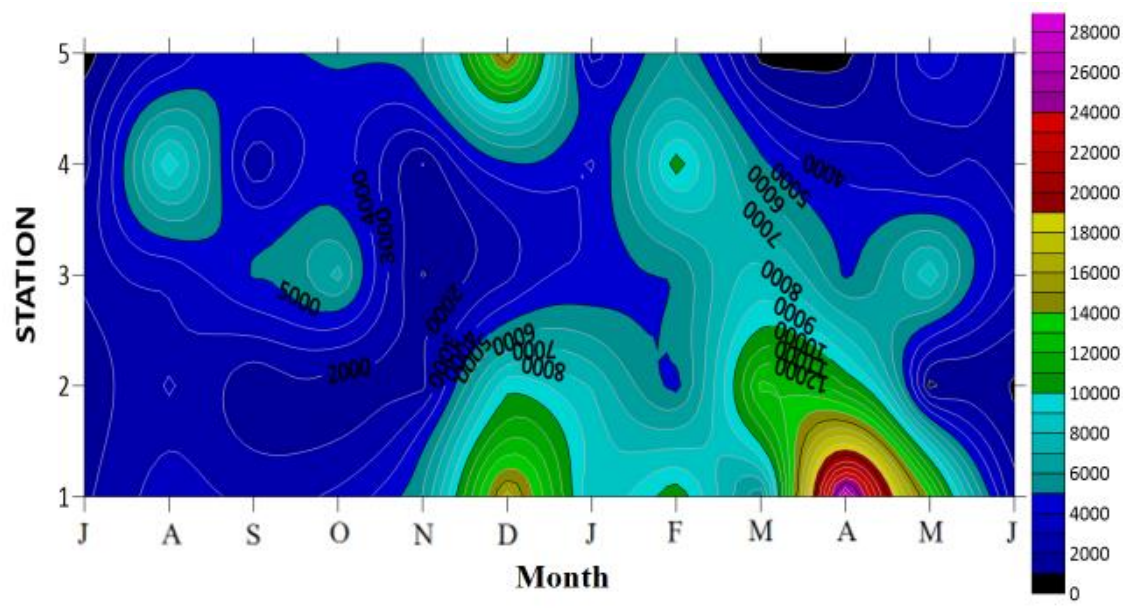

Figure 3. The monthly zooplankton abundance (ind $/ \mathrm{m}^{3}$ ) at Batang Lupar and Batang Sadong (Sarawak, Malaysia) estuarine complex during the study period 


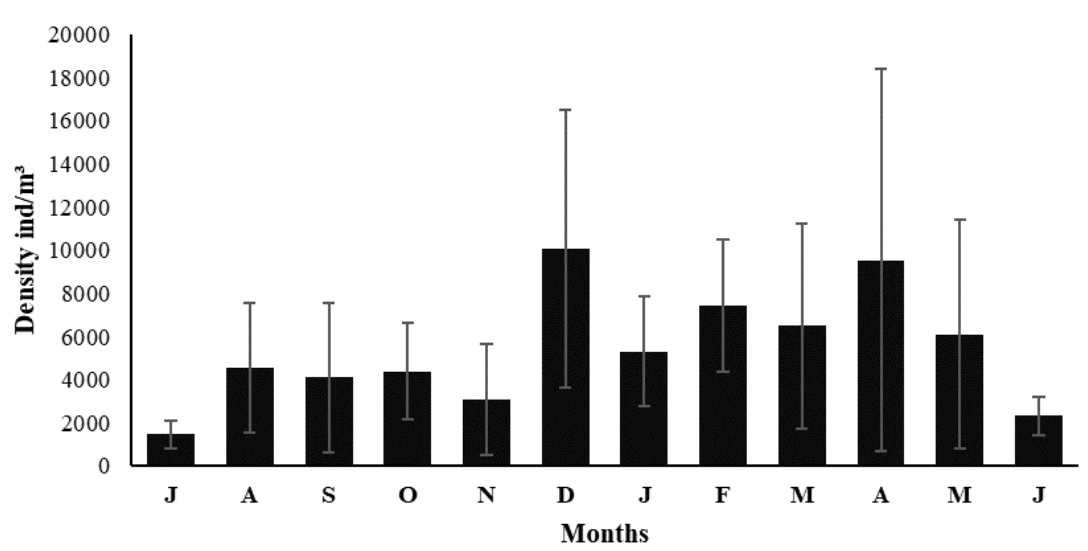

Figure 4. The monthly average abundance of total zooplankton from Batang Lupar and Batang Sadong estuaries, Sarawak, Malaysia during the study period

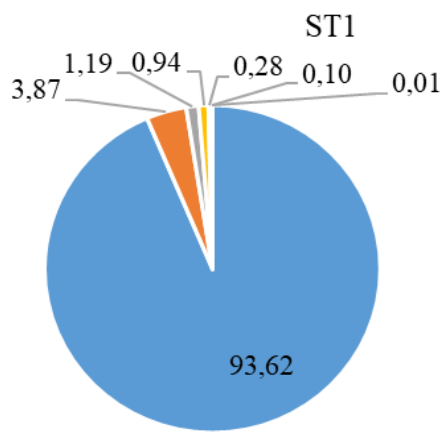

ST3
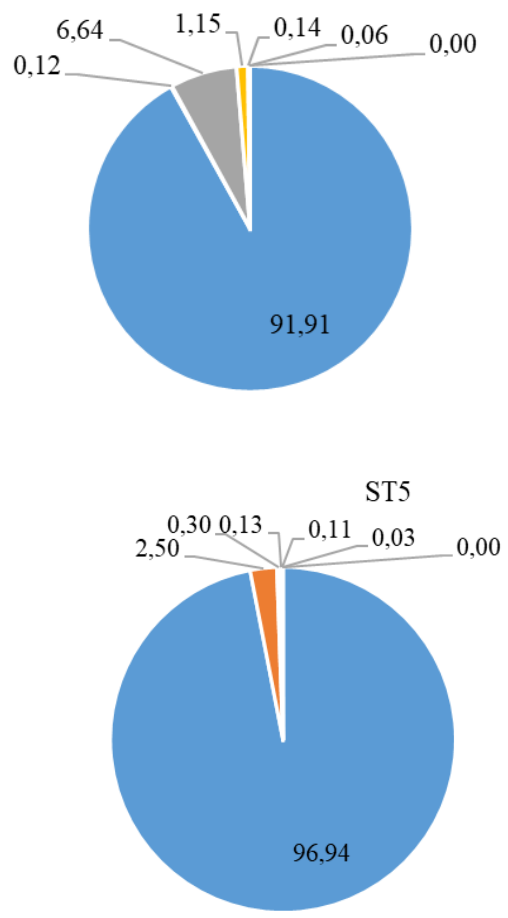

ST2

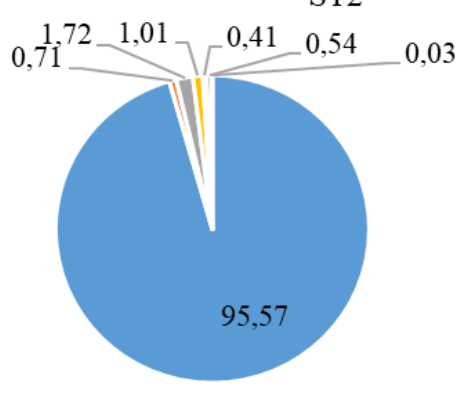

- Arthropoda

- Mollusca

- Chaetognatha

- Polychaeta

- Chordata

- Cnidaria

- Echinodermata

- Arthropoda

- Mollusca

- Chaetognatha

- Polychaeta

- Chordata

- Cnidaria

- Echinodermata

$$
\begin{aligned}
& \text { - Arthropoda } \\
& \text { - Mollusca } \\
& \text { - Chaetognatha } \\
& \text { - Polychaeta } \\
& \text { - Chordata } \\
& \text { - Cnidaria } \\
& \text { - Echinodermata }
\end{aligned}
$$

Figure 5. Percentage of the zooplankton group from July 2016 until June 2017 in the study areas (ST1-ST5) 

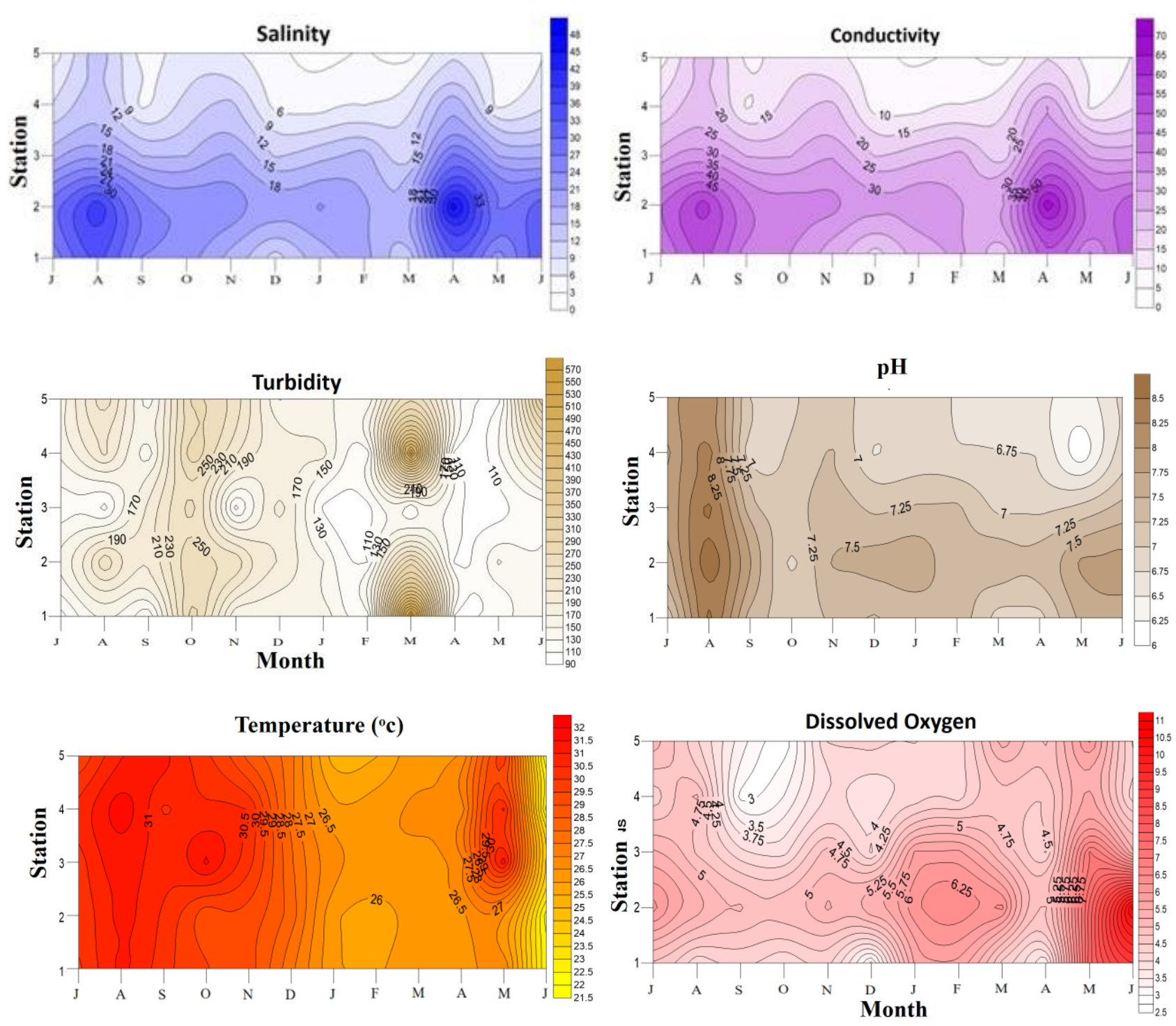

Figure 6. The monthly water quality parameter (in-situ ecological parameter) in Batang Lupar and Batang Sadong estuaries, Sarawak, Malaysia during the study period

\section{Inter-station cluster analysis}

Cluster analysis of zooplankton abundance in all 5 stations revealed a clear inter-stational grouping. The dendrogram presented the zooplankton density in total number of stations (5) were generally classified into 2 groups at the similarity level of 0.90 based on the difference of stations (Figure 9). Station 1 was clearly separated from another cluster comprised of Stations 2-5.

\section{Canonical correspondence analysis (CCA)}

The first canonical axis accounted for $44.65 \%$ and the second axis accounted for $25.17 \%$ of the variance in the zooplankton abundance. Thus the first two axes cumulatively explain $69.82 \%$ of the variance. The third canonical axis accounted for $21.42 \%$ and altogether the value represents $91.24 \%$. CCA model confirmed that key abiotic factors notably Turbidity and nitrate $\left(\mathrm{NO}_{3}-\mathrm{N}\right)$ were highly correlated with individual groups of zooplankton abundance. Here, ecological parameters such as Turbidity (eigenvalue: 0.044 ) and nitrate (eigenvalue: 0.025 ) were highly correlated among all other parameters (Figure 10). Zooplankton groups Cirripedia larvae, mollusks, amphipods, were found to be closely associated with turbidity content of water (Figure 10). 

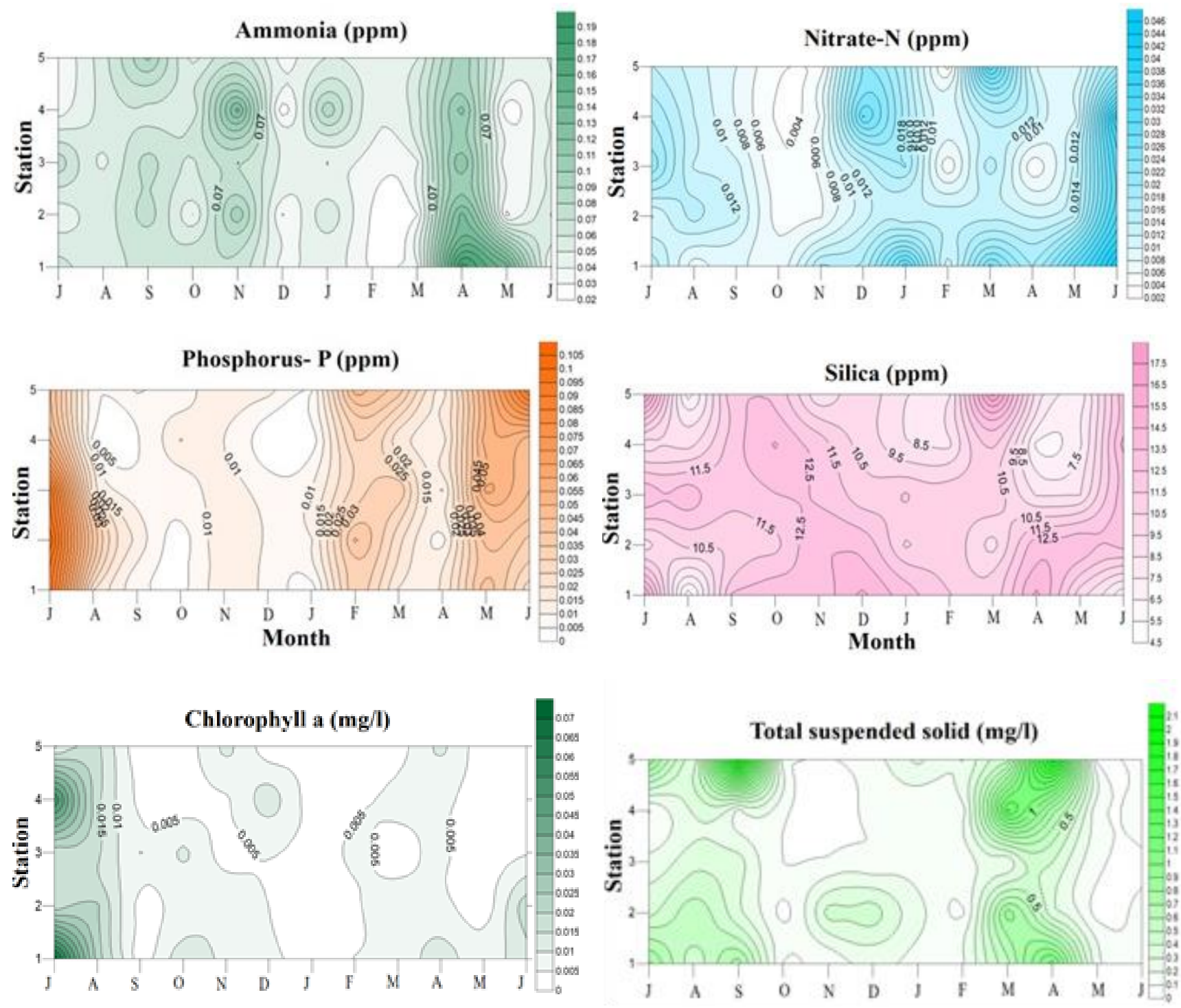

Figure 7. The monthly water quality parameters in Batang Lupar and Batang Sadong estuaries, Sarawak, Malaysia during the study period

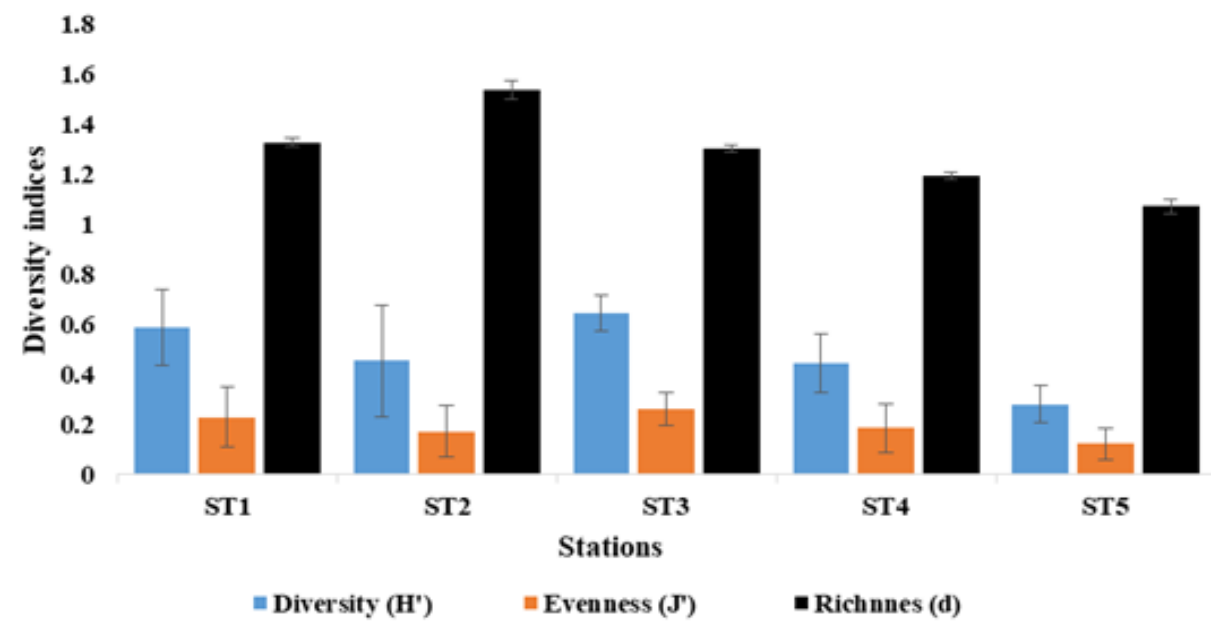

Figure 8. Diversity, evenness and richness index of zooplankton at Batang Lupar and Batang Sadong estuaries, Sarawak, Malaysia 
Table 4. The similarity of zooplankton population abundance analyzed by one-way ANOSIM (PAST-3.25) during study periods for 5 stations

\begin{tabular}{cccccc}
\hline & S1 & S2 & S3 & S4 & S5 \\
\hline S1 & & 0.176 & 0.326 & 0.251 & 0.298 \\
S2 & 0.175 & & 0.112 & 0.433 & 0.291 \\
S3 & 0.326 & 0.112 & 0.617 & & 0.671 \\
S4 & 0.251 & 0.431 & 0.671 & 0.575 & 0.575 \\
S5 & 0.298 & 0.291 & & \\
\hline
\end{tabular}

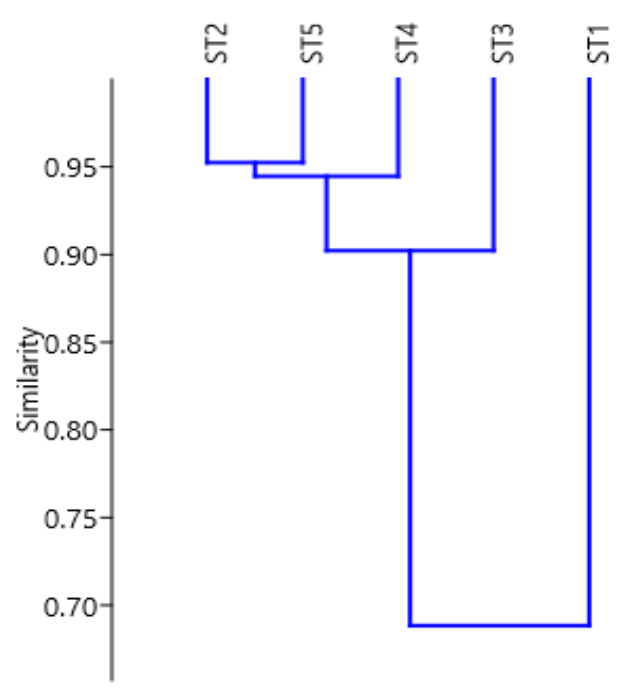

Figure 9. Dendrogram based on Bray-Curtis similarity between of zooplankton density in different stations in the study area

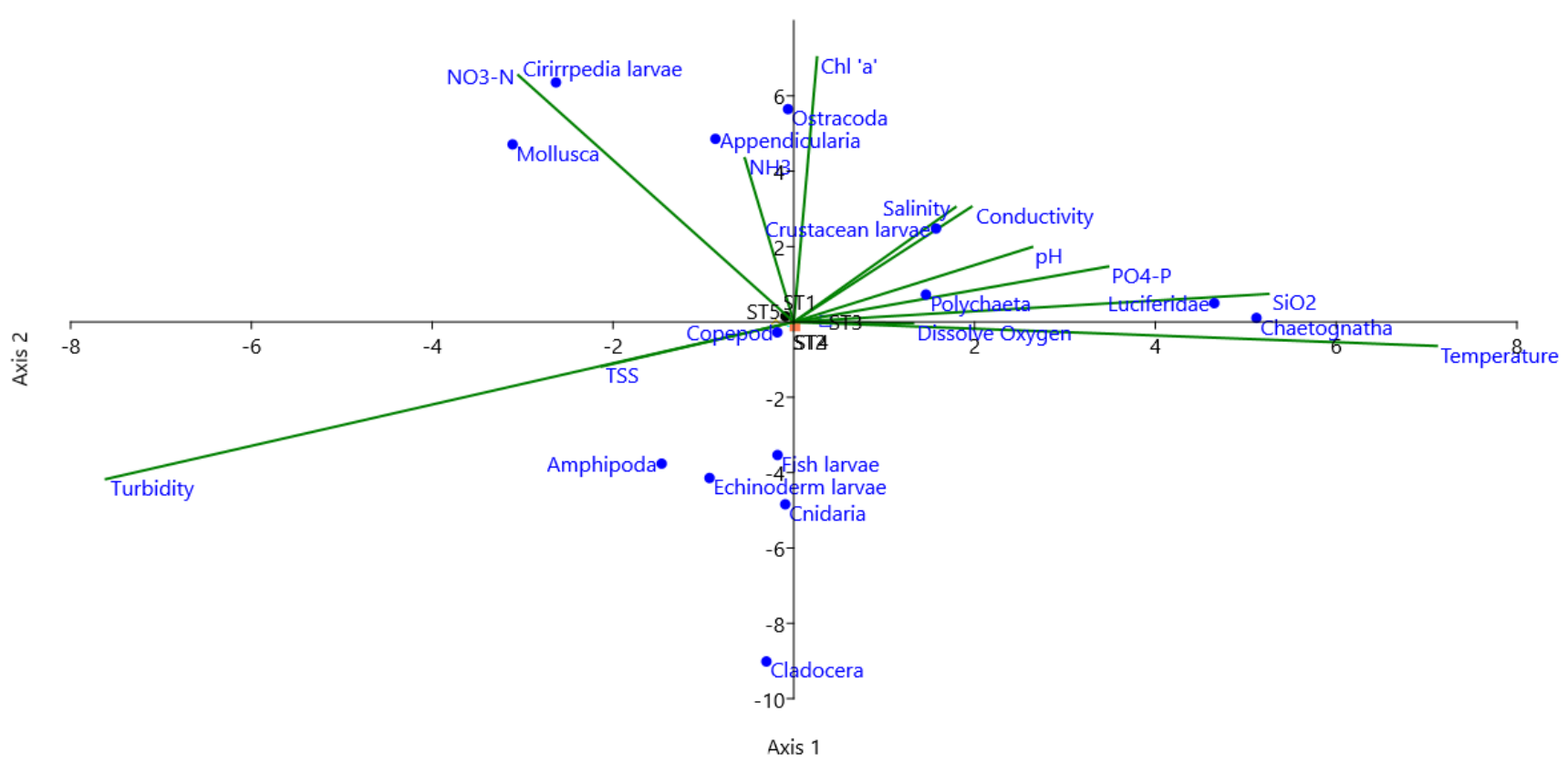

Figure 10. Canonical correspondence analysis (CCA) ordination depicting relationships among abundances of zooplankton and environmental variables 
Table 5. Comparison of zooplankton abundance with other studies in Malaysia

\begin{tabular}{llll}
\hline Habitat & Zooplankton & Mesh size & Reference \\
\hline Marudu Bay estuaries & 1243 to $1553 \mathrm{ind} / \mathrm{m}^{3}$ & $20 \mu \mathrm{m}$ & Tan and Ransangan (2017) \\
Lukut estuary, Negeri Sembilan & $104300 \mathrm{ind} / \mathrm{m}^{3}$ & $150 \mu \mathrm{m}$ & Musa and Singh (2015) \\
Merbok estuary Kedah & $361 \times 10^{3} \mathrm{ind} / \mathrm{m}^{3}$ & $150 \mu \mathrm{m}$ & Fatema and Omar (2016) \\
Seagrass meadow Johor, Malaysia & $17.0 \times 10^{4} \mathrm{ind} / \mathrm{m}^{3}$ & $100 \mu \mathrm{m}$ & Matias-Peralta and Yusoff (2015) \\
Seagrass bed, Merambong shoal & 3030.16 to $4006.5 \mathrm{ind} / \mathrm{m}^{3}$ & $140 \mu \mathrm{m}$ & Azmi et al. (2016) \\
Mangrove estuary, Malaysia & $12330-20311 \mathrm{ind} / \mathrm{m}^{3}$ & $180 \mu \mathrm{m}$ & Chew and Chong (2011) \\
Coast of Klang Strait, Malaysia & $30951-55756 \mathrm{ind} / \mathrm{m}^{3}$ & $180-363 \mu \mathrm{m}$ & Chew and Chong (2016) \\
Borneo coastal waters & 232 to $251 \mathrm{ind} / \mathrm{m}^{3}$ & $0.03 \mathrm{~mm}$ & Jivaluk (1999) \\
Seagrass bed, Pulau Tinggi, Johor & $1245 \mathrm{ind} / \mathrm{m}^{3}$ & $100 \mu \mathrm{m}$ & Shuaib et al. (2019) \\
Straits of Malacca & $9202 \mathrm{ind} / \mathrm{m}^{3}$ & $140 \mu \mathrm{m}$ & Rezai et al. (2011) \\
Batang Lupar and Batang Sadong estuary, Sarawak & $447.5 \mathrm{to} 27812.9 \mathrm{ind} / \mathrm{m}^{3}$ & $150 \mu \mathrm{m}$ & Present study \\
\hline
\end{tabular}

\section{Discussion}

The research focused on the studies of zooplankton recently due to its functions in the aquatic ecosystems as live food and a contributor to the secondary consumers of the riverine ecosystem. Zooplankton also plays a key environmental indicator in any aquatic ecosystem as well as works an important role in the aquatic food chain. A total of 29 spp. with 14 major groups of zooplankton was recorded in the present study, which is a moderate number of species compared to other studies; that is lower than the value recorded (91 spp.) by Chew et al. (2015) in coastal estuaries, Abu Hena et al. (2016) in mangrove estuary (33 sp.) and Tinggi and Sibu Islands (129 sp.) Malaysia (Metillo et al. 2018), and higher than the value of Straits of Johor (Kassim et al. 2015) and Sungai Lukut (Musa and Singh 2015).

A comparison of the zooplankton number and abundance of the present study with other studies is presented in Table 5. The range of total abundance of zooplankton was found from 447.5 to $27812.9 \mathrm{ind} / \mathrm{m}^{3}$ representing from 5 stations, which is coincided with the findings from some coastal and estuarine waters (Table 5). The abundance of zooplankton recorded from these 2 estuarine habitats was higher than that of $\left(232 \pm 125 \mathrm{ind} / \mathrm{m}^{3}\right)$ reported by Jivaluk (1999) in Sabah, Sarawak and Brunei Darussalam waters and comparable to that of recorded in Matang mangroves, Marudu Bay estuaries and Straits of Malacca (Table 5). Generally, different estuarine and coast have a different environmental setting (Blaber 1997) due to the different tidal range, freshwater input, geomorphology, and human pressure (McLusky and Elliott 2004), which can also be driving force in a variation of the abundance of zooplankton in a different regime.

Studies revealed that crustaceans, especially copepods form a major portion of the zooplankton community in most of the estuarine regime (Abu Hena et al. 2016). In the present study, copepods were found occupying $88.38 \%$ of the total zooplankton, which is lower than that of $94.7 \%$ reported by Zulikha et al. (2013) in Perak river, Malaysia. In the context of the number of species, the present finding revealed lower than that of 49 species identified from the Bintulu coast (Johan et al. 2013) and 48 species in Sangga estuary, Malaysia (Chew and Chong 2011). It is assumed that different factors such as sampling apparatus, duration, and area of coverage could attribute to the different findings regarding species composition (Johan et al. 2013). Calanoida constituted a large number of species of copepod in the present study, which coincided, with the findings of Johan et al. (2012) probably due to their continuous breeding behavior, quick larval development and the adaptation to the widely changing environment in the estuary (Perumal et al. 2009).

Copepod contributes about 477.37-25921.89 ind $/ \mathrm{m}^{3}$, and $88.38 \%$ of total zooplankton followed by crustacean larvae $5.88 \%$, Chaetognatha $2.32 \%$, Mollusca $1.95 \%$, Polychaeta $0.85 \%$ and others $(0.59 \%)$. Zooplankton abundance was higher $\left(8460.72 \mathrm{ind} / \mathrm{m}^{3}\right)$ in station 1 followed by station $2\left(5479.80 \mathrm{ind} / \mathrm{m}^{3}\right)$, station $3(4571.95$ ind $\left./ \mathrm{m}^{3}\right)$, station $4\left(4394.2 \mathrm{ind} / \mathrm{m}^{3}\right)$ and station $5(4156.73$ ind $/ \mathrm{m}^{3}$ ). It is probably due to higher nutrient input in station 1 from adjacent mangrove ecosystems as noticed by other studies elsewhere (Abu Hena et al. 2016). The highest total means zooplankton abundance (10070.39 ind $\left./ \mathrm{m}^{3}\right)$ was recorded in December 2016 while the lowest abundance (1461.47 ind $/ \mathrm{m}^{3}$ ) was observed in July 2016. The higher abundance of zooplankton in December could be directed by nutrient supply due to higher precipitation in this area, which provides a favorable condition for zooplankton development (Abu Hena et al. 2016). This finding is similar to the studies of Yoshida et al. (2012); Chew et al. (2015); Kassim et al. (2015) and Tan and Ransangan (2017) in other tropical and sub-tropical coasts.

Species richness index (1.07 to 1.54$)$ was higher at station 2 (1.54) which referred to the higher number species that was found in the downstream area, and populated by a diverse salinity tolerant species found in the mouth of the estuary. In the upstream area (station 5), a lower richness index (1.07) was recorded and these areas were dominated by freshwater species. The Shannon index was higher at station 3 (0.64) and lower at station 5 (0.27) while the Evenness index was 0.25 and 0.12 respectively. These indices showed that the species homogeneity of the downstream area stations (station 3) was higher because this station represented the end-point of downstream areas and the start-point of upstream areas. Station 5 (upstream) showed lower homogeneity of species; zooplankton species assemblage of these areas was very scattered. These are similar to the findings of Abu Hena et al. (2016) and Ismail 
and Zaidin (2015). The present study also revealed that the zooplankton composition was similar between some stations and these stations were considered sharing a similar habitat (Table 4). A similar observation was also found by Favier and Winkler (2014) at St Lawrence estuarine transition zone, Chen and Liu (2015) in the Yellow Sea and the East China Sea and Bhat et al. (2014) at tropical wetland India.

Cluster analysis of zooplankton abundance in all five stations revealed a clear inter-stational grouping. The dendrogram presented the zooplankton abundance in the total number of stations (5) were generally classified into 2 groups at the similarity level of 0.90 based on the difference of stations. The cluster analysis of the present study was very relevant with the study of Johan et al. (2012) at Perai river estuary, Penang, Malaysia, and Razak et al. (2016) at tropical mangrove estuary in the Straits of Malacca, Malaysia.

Based on CCA, there was no similarity between ecological and zooplankton abundance with the present study. However, Metillo et al. (2018) showed the same sort of CCA elsewhere. The present study found that copepod was the dominant group in the abundance and composition of zooplankton could probably due to good environment support because these species are very useful for coastal and estuarine fishery resources in this estuarine environment and associated with water turbidity and nitrate.

The rivers of Sarawak harbors diverse groups of zooplankton and could have significant contributions on the breeding ground for different fish species. Different ecological parameters were influenced the zooplankton abundance, diversity, and distribution. The zooplankton population in the Tenualosa toli habitat exhibited some degree of population diversity, stable uniformity, and evenly distributed. Zooplankton population on these estuarine ecosystems can be used as an indicator of a healthy aquatic ecosystem. Further study of influences on zooplankton composition and abundance with the ecological association on any other fish species, which is available in these estuarine habitats, is highly recommended.

\section{ACKNOWLEDGEMENTS}

The author is gratefully acknowledgments to TRGS (TRGS/1/2015/UPM/01/13/3) by the Ministry of Higher Education, Malaysia for providing financial assistance to carry out the present research work and Department of Agriculture, Sarawak for support for sampling activity during the study period.

\section{REFERENCES}

Abdullah M, Akhtar A, Abu Hena MK, Islam MS, Uddin MM, Alam MD, $\mathrm{Xu}$ H. 2018. Seasonal pattern of zooplankton communities and their environmental response in subtropical maritime channels systems in the Bay of Bengal, Bangladesh. Acta Ecol Sin 38 (4): 316-324.
Abu Hena MK, Japar Sidik B, Idris MH, Johan I, Nesarul NH, Aysha A, Islam MS. 2016. Seasonal distribution of zooplankton composition and abundance in a subtropical mangrove and salt marsh estuary. Malays J Sci 35 (2): 257-270.

Azmi AA, Yoshida T, Toda T, Ross, Obin H, Cob ZC. 2016. Comparison of zooplankton abundance and community in seagrass and nonseagrass areas of Merambong shoal. AIP Conf Proc 1784: 060002. DOI: $10.1063 / 1.4966840$

Bhat NA, Wanganeo A, Raina R. 2014. The composition and diversity of net zooplankton species in a tropical water body (Bhoj Wetland) of Bhopal, India. Intl J Biodiv Conserv 6 (5): 373-381.

Blaber SJM. 1997. Fish and Fisheries of Tropical Estuaries. Chapman and Hall Publisher, London, UK.

Buttay L, Miranda A, Casas G, González-quirós R, Nogueira E. 2015. Long-term and seasonal zooplankton dynamics in the northwest Iberian shelf and its relationship with meteo-climatic and hydrographic variability. J Plankton Res 38 (1): 106-121.

Chihara M, Murano M. 1997. An Illustrated Guide to Marine Plankton in Japan. Tokai University Press, Japan.

Chen H, Liu G. 2015. Zooplankton community structure in the Yellow Sea and East China Sea in autumn. Braz J Oceanogr 63 (4): 455-468.

Chew LL, Chong VC, Wong RCS, Lehette P, Ng CC, Loh KH. 2015. Three decades of seawater abstraction by Kapar power plant (Malaysia): What impacts on tropical zooplankton community? Mar Poll Bull 101 (1): 69-84.

Chew LL, Chong VC. 2011. Copepod community structure and abundance in a tropical mangrove estuary, with comparisons to coastal waters. Hydrobiol 666 (1): 127-143.

Chew LL, Chong VC. 2016. Response of marine copepods to a changing tropical environment: winners, losers and implications. Peer J 4: e2052. DOI: $10.7717 /$ peerj.2052

Cook RB, Bunker A, Hay S, Hirst AG, Speirs DC. 2007. Studied the naupliar development times and survival of the copepods Calanus helgolandicus and Calanus finmarchicus in relation to food and temperature. J Plankton Res 29 (9): 757-767.

Dang PD, Khoi NV, Nga TTN, Thanh DN, Hai HT. 2015. Identification Handbook of Freshwater Zooplankton of the Mekong River and its Tributaries. Mekong River Commission, Vientiane.

Fatema K, Omar WMW. 2016. Population dynamics of zooplankton in Merbok Estuary, Kedah, Malaysia in relation to some water quality parameters. Dhaka Univ J Biol Sci 25 (1): 47-55.

Favier JB, Winkler G. 2014. Coexistence, distribution patterns and habitat utilization of the sibling species complex Eurytemora affinis in the St Lawrence estuarine transition zone. J Plankton Res 36 (5): 12471261 .

Edwards AM. 2001. Adding detritus to a nutrient-phytoplanktonzooplankton model: A dynamical-systems approach. J Plankt Res 23(4): 389-413

Harrison TD. 2004. Physico-chemical characteristics of South African estuaries in relation to the zoogeography of the region. Est Coast Shelf Sci 61 (1): 73-87.

Hossain MS, Gopal DN, Sarker S, Rahaman MZ. 2012. Fish diversity and habitat relationship with environmental variables at Meghna river estuary, Bangladesh. Egypt J Aqua Res 38 (3): 213-226.

Ismail AH, Adnan AAM. 2016. Zooplankton composition and abundance as indicators of eutrophication in two small man-made lakes. Trop Life Sci Res 27: 31-38. DOI: 10.21315/tlsr2016.27.3.5

Ismail AH, Zaidin SA. 2015. A Comparative Study of Zooplankton Diversity and Abundance from Three Different Types of Water Body. 2nd International Conference on Agriculture, Environment and Biological Sciences (ICAEBS'15). Bali, August 16-17, 2015.

Jivaluk J. 1999. Distribution, Abundance and Composition of Zooplankton in the South China Sea, Area II: Sabah, Sarawak and Brunei Darussalam Waters. Proceedings of the Second Technical Seminar on Marine Fishery Resources Survey in the South China Sea, Area II: West Coast of Sabah, Sarawak and Brunei Darussalam. Kuala Lumpur, 14-15 December 1998.

Johan I, Abu Hena MK, Idris MH, Arshad A. 2013. Taxonomic composition and abundance of zooplankton Copepoda in the coastal waters of Bintulu, Sarawak, Malaysia. J Fish Aqua Sci 8: 472-479. DOI: $10.3923 /$ jfas.2013.472.479

Johan I, Wan Maznah WO, Mashhor M, Abu Hena MK, Amin SMN. 2012. Spatial distribution of copepods along the salinity gradient of Perai River estuary, Penang, Malaysia. Pak J Biol Sci 15: 647-652. DOI: $10.3923 /$ pjbs.2012.647.652 
Kamaruzaman NFS, Kassim Z, Jasmani S, Mohtar NF. 2018. Seasonal variations of harpacticoid copepod and size-fractionated abundances in relation to environmental changes in Setiu Wetland. J Env Biol 39 (5): 883-887.

Kassim Z, Yunus K, Jalal KCA, Jaafar IN, Nordin NS, Ahmad WMAW, Ismail A, John AB. 2015. Spatial distribution trend of plankton in Sungai Pulai Estuary, the Straits of Johor, Malaysia. Sains Malay 44 (9): 1257-1262.

Kasthuriranagn LR. 1963. Key to the identification of the common pelagic copepods of Indian coastal waters. CSLS publication, Canada.

Lee CL. 2012. Dynamics and Trophic Role of Zooplankton Community in the Matang Mangrove Estuaries and Adjacent Coastal Waters (Peninsular Malaysia), with Special Emphasis on Copepods. [PhD Dissertation]. Universiti Malaya, Kuala Lumpur, Malaysia.

Marcolin CR, Gaeta S, Lopes RM. 2015. Seasonal and interannual variability of zooplankton vertical distribution and biomass size spectra off Ubatuba, Brazil. J Plankton Res 37 (4): 808-819.

Matias-Peralta HM, Yusoff FM. 2015. Status of planktonic copepod diversity in the Merambong Seagrass Meadow, Johor, Peninsular Malaysia. Intl J Ecosys 5 (2): 39-43.

McLusky DS, Elliott M. 2004. The Estuarine Ecosystem: Ecology, Threats, and Management. Oxford University Press, Oxford.

Metillo EB, Nishikawa J, Ross OB, Yoshida T, Yusoff FM, Kuppan P, Nishida S. 2018. Diel patterns of Zooplankton community structure in nearshore waters of different substrates off Tinggi and Sibu Islands, Malaysia, with special reference to Copepods. Aqua Ecosys Heal Man. DOI:10.1080/14634988.2018.1505139

Mohsin AKM, Ambak MA. 1996. Marine Fishes and Fisheries of Malaysia and Neighboring Countries. Universiti Pertanian Malaysia Press, Serdang, Malaysia.

Motodo S. 1959. Devices of simple plankton apparatus. Memoir Fac Fish Hokkaido Univ 7 (1\&2): 73-94.

Musa SF, Singh HR. 2015. Zooplankton Community Structure of Sungai Lukut and its Estuary, Negeri Sembilan. Proceedings of ISER 10th International Conference. Kuala Lumpur, 8 November 2015

Paturej E, Gutkowska A, Koszałka J, Bowszys M. 2017. Effect of physicochemical parameters on zooplankton in the brackish, coastal Vistula Lagoon. Oceanol 59 (1): 49-56.

Perumal NV, Rajkumar M, Perumal P, Rajasekar KT. 2009. Seasonal variations of plankton diversity in the Kaduviyar estuary, Nagapattinam, southeast coast of India. J Environ Biol 30 (6): 1035 1046.

Rahim KAA, Tumiran MHL Shabdin M, Esa Y, Husaini ASA. 2014. The Status of Tenualosa toli (Valenciennes, 1847) in the Southwest Coast of Sarawak, Malaysia. Kuroshio Sci 8: 37-42.

Razak SBA, Yusoff FM, Arshad AB, Nishikawa J. 2016. Seasonal variations of zooplankton biomass and size-fractionated abundance in relation to environmental changes in a tropical mangrove estuary in the Straits of Malacca. J Environ Biol 37 (4): 685-695.

Rezai H, Yusoff FM, Othman BHR. 2011. Vertical distribution of zooplankton and copepod community structure in the Straits of Malacca. J Persian Gulf (Mar Sci) 2 (3): 17-23.

Saidin ANB. 2016. Water Quality and Zooplankton Community Structure of Tembat River, Hulu Terengganu. [Thesis]. Universiti Sains Malaysia, Pulau Pinang.
Saifullah ASM, Abu Hena MK, Idris MH, Halima AR, Johan I. 2014 Seasonal variation of water characteristics in Sibuti river estuary in Sarawak, Malaysia. Malays J Sci 33 (1): 9-22.

Sameoto D, Wiebe P, Runge J, Postel L, Dunn J, Miller C, Coombs S. 2000. Collecting zooplankton. In: Harris R, Wiebe P, Lenz J, Skjoldal HR, Huntley M (eds). ICES Zooplankton Methodology Manual. Academic Press, New York.

Shuaib N, Mohammad M, Matias-Peralta HM, Rusiman MS, Sanusi SB. 2019. Copepods status in seagrass area of Pulau Tinggi Marine Park, Johor, Malaysia. IOP Conf. Series: Earth Environ Sci 269: 012044. DOI: $10.1088 / 1755-1315 / 269 / 1 / 012044$

Sinev AY, Yusoff FM. 2015. Cladocera (Crustacea: Branchiopoda) of Sabah State in Borneo Island, Malaysia. Zootaxa 4000 (5): 581-591.

Sinev AY, Yusoff FM. 2018. New data on Cladocera (Crustacea: Branchiopoda) of Sabah State, Borneo Island, Malaysia. Zootaxa 4438 (2): 362-372.

Smith PE, Counts RC, Clutter RI. 1968. Changes in filtering efficiency of plankton nets due to clogging under tow. ICES J Mar Sci 32 (2): 232248.

Srichandan S, Panda CR, Rout NC. 2013. Seasonal distribution of zooplankton in Mahanadi estuary (Odisha), East coast of India: A taxonomical approach. Intl J Zoo Res 9 (1): 17-31.

Tan KS, Ransangan J. 2017. Effects of nutrients and zooplankton on the phytoplankton community structure in Marudu Bay. Estuar Coast Shel Sci 194: 16-29. DOI: 10.1016/j.ecss.2017.05.008

Thirunavukkarasu K, Soundarapandian P, Varadharajan D, Gunalan B. 2013. Zooplankton composition and community structure of Kottakudi and Nari backwaters, South East of Tamil Nadu. J Environ Anal Toxicol 4: 200. DOI: 10.4172/2161-0525.1000200

Tumiran MHB, Rahim KAA, Shabdin ML, Esa Y, Husaini AASA. 2011. Environmental Parameters of "Core Terubok Areas" and the Relationship with Terubok Sarawak Population. International Fisheries Symposium. Universiti Malaysia Terengganu, Kuala Nerus, October 2011.

U.S. Environmental Protection Agency [EPA]. 2008. EPA's 2008 Report on the Environment. National Center for Environmental Assessment, Washington, DC; EPA/600/R-07/045F. Available from the National Technical Information Service, Springfield, VA. http://www.epa.gov/roe.

Wiebe PH, Allison D, Kennedy M, Moncoiffé G. 2014. A vocabulary for the configuration of net tows for collecting plankton and micronekton. J Plankton Res 37 (1): 21-27.

Yong YL, Chew LL, Lee CW, Chong VC. 2016. Monsoonal and lunar variability in microzooplankton abundance and community structure in the Terusan mangrove creek (Malaysia). Mar Biol Res 12 (3): 278293. DOI: $10.1080 / 17451000.2016 .1143107$

Yoshida T, Matias-Peralta H, Yusoff FMD, Toda T, Othman BHR. 2012. Zooplankton research in Malaysia: Current status and future prospects. Coast Mar Sci 35 (1): 208-213.

Zaleha K, Abang Jefri AM, Hasimah MS. 2013. Fauna of Porcellidiidae (Copepoda: Harpacticoida) from Sungai Pulai, Malaysia. Malay Nat J 64 (4): 159-167.

Zulikha NZ, Yusoff FM, Nishikawa J, Arshad A, Matias-Peralta HM. 2013. Mesozooplankton composition and abundance in a tropical estuary during monsoon season. J Fish Aqua Sci 8 (3): 430-440. 